Journal of Health Promotion and Behavior (2018), 3(4): 240-247

https://doi.org/10.26911/thejhpb.2018.03.04.03

\title{
The Contextual Effect of School on the Premarital Sex among Adolescents in Bantul, Yogyakarta
}

\author{
Galuh Tunjung Pertiwi'1), Hanung Prasetya ${ }^{2}$, Bhisma Murti3) \\ 1)Masters Program in Public Health, Universitas Sebelas Maret \\ 2)Faculty of Medicine, Universitas Sebelas Maret
}

\begin{abstract}
Background: Previous studied have identified individual and school-level characteristics that are associated with sexual risk-taking. But similar studies in Indonesia is lacking. This study aimed to examine the contextual effect of school on the premarital sex among adolescents in Bantul, Yogyakarta.

Subjects and Method: This was a cross sectional study carried out at 25 senior high schools in Bantul, Yogyakarta, from November to December 2018. A sample of 225 adolescents aged 15-18 years was selected by stratified random sampling. The dependent variable was premarital sex. The independent variables were intention, subjective norm, perceived behavior control, family intimacy, and peer group. The data were collected by questionnaire and analyzed by a multilevel logistic regression on Stata 13.

Results: Premarital sex incrased with favorable intention $(b=2.70 ; 95 \% \mathrm{CI}=0.50$ to $3.15 ; \mathrm{p}=$ 0.007), subjective norm $(b=4.66 ; 95 \% \mathrm{CI}=1.89$ to $4.63 ; \mathrm{p}<0.001)$, and suitable peer group $(\mathrm{b}=$ 4.34; $95 \% \mathrm{CI}=1.99$ to $5.28 ; \mathrm{p}<0.001)$. Premarital sex decreased with positive attitude $(\mathrm{b}=-4.31$; $95 \% \mathrm{CI}=-4.15$ to $-1.55 ; \mathrm{p}<0.001)$, strong perceived behavior control $(\mathrm{b}=-2.37 ; 95 \% \mathrm{CI}=-2.53$ to $0.23 ; \mathrm{p}=0.018)$, and strong family intimacy $(\mathrm{b}=-2.44 ; 95 \% \mathrm{CI}=-2.69$ to $0.29 ; \mathrm{p}=0.015)$. There was contextual effect of school on premarital sex with ICC $=63.72 \%$.

Conclusion: Premarital sex incrases with favorable intention, subjective norm, and suitable peer group. Premarital sex decreases with positive attitude, strong perceived behavior control, and strong family intimacy. There is contextual effect of school on premarital sex, which calls for attention.
\end{abstract}

Keywords: premarital sex, school, multilevel analysis

\section{Correspondence:}

Galuh Tunjung Pertiwi. Masters Program in Public Health, Universitas Sebelas Maret, Surakarta, Jl. Ir. Sutami No. 36 A, Surakarta 57126, Central Java. Email: galuhpertiwi2017@gmail.com. Mobile: +6281229722373 .

\section{BACKGROUND}

Adolescents are residents between the ages of 10-19 years, and are often considered a healthy group (WHO, 2012), while according to Regulation of the Minister of Health of Republic of Indonesia number 25 in 2014, adolescents are residents with an age range of 10-18 years. The National Population and Family Planning Board (BKKBN) in Kusumaryani (2017) define teenagers as someone 10-24 years old and unmarried. Adolescence is a period of transition from children to adulthood and at this time ado- lescents experience physical, sexual, and psychological changes (WHO, 2015). Because of differences in definitions, there is no limit to the age range of adolescents. In this study, the age range of teenagers is 15-19 years because at this time adolescents experience a period of transition and narrow the population of adolescents in Bantul Regency.

Nowadays, adolescents face various health problems, especially reproductive health and sexuality, one of which is unwanted pregnancy. There are 3 million girls 
experiencing unwanted pregnancies and unsafe abortions (WHO, 2012). Every year in developing countries, an estimated 21 million adolescent girls aged 15-19 years and 2 million adolescent girls become pregnant under the age of 15 (Darochet et al., 2016). About $11 \%$ of female adolescents aged 15-19 years who give birth, are mostly in developing countries and low income countries (United Nation, 2017).

Every day in developing countries, 20,000 girls under the age of 18 give birth. This number reaches 7.3 million births per year. Birth of adolescents aged 15-19 years is $95 \%$ in low and middle income countries. Every year, there are 3 million adolescents who have unsafe abortions, risk their lives and health, teenagers have the desire to get their rights as teenagers to go back to school (UNFPA, 2017). Data on the SDGs indicator for adolescent birth rates globally in 2015 showed that there were 44 births per 1,000 teenagers. In Indonesia the birth rate of adolescents in the year is 48 births per 1,00o teenagers (United Nation, 2017).

The SDGs program is in third place, which ensures healthy living and improving well-being for all ages. One target is that by 2030, access to sexual and reproductive health care services, including family planning, information and education, and the integration of reproductive health into national strategies and programs are achieved (United Nation, 2017). Adolescent physiological development and its impact on sexual behavior are influenced by hormonal and gender factors. Adolescent girls are more easily influenced by psychosocial factors, including the influence of peer groups (Skinner et al., 2015). In addition, behavioral problems in young women are a risk factor for early sexual intercourse. Therefore, the development of health program interventions related to adolescent sexual health is urgently needed (Pringleet al, 2017). Factors that influence adolescent premarital sex behavior include affection, socio-economic, peers, pleasure factors, and educational reasons (Abdullahi and Umar, 2013). Adolescents involved in premarital sexual behavior have several factors which include feelings of love, sexual drive, and pressure from partners, curiosity, peer pressure, and rape (Chihurumnanya et al., 2016).

Based on this, the author interested in conducting study on the contextual influence of schools on premarital sexual behavior in adolescents.

\section{SUBJECTS AND METHOD}

\section{Study Design}

This was a cross sectional study conducted at 25 senior high schools in Bantul, Central Java, from November to December 2018.

\section{Population and Samples}

Population was all adolescents aged 15-18 years old in Bantul, Central Java. A sample of 225 adolescents was selected by simple random sampling.

\section{Study Variables}

The dependent variable was premarital sex behavior. The independent variables were intention, subjective norm, peer, perceived behavior control, family intimacy, and school.

\section{Operational definition of variables}

Intention was defined as the desire of teenagers to do or not engage in sexual behavior before marriage. The stronger the intention, the greater the adolescent for premarital sex. The measurement scale was continous and transformed into dichotomous, coded o for weak intention and 1 for strong intention.

Attitude was defined as a response of adolescents with positive or negative judgements related to feelings that support or do not support premarital sexual behavior. The more teenagers have a positive attitude, the 
Journal of Health Promotion and Behavior (2018), 3(4): 240-247

https://doi.org/10.26911/thejhpb.2018.03.04.03

more they support adolescents to have premarital sex. The measurement scale was continous and transformed into dichotomous, coded $\mathrm{o}$ for negative and 1 for positive.

Subjective norm was defined as a belief in support for adolescents from the social environment, family members, and peers who influence adolescent decision making in conducting or not engaging in premarital sexual behavior. The more subjective norms support the existence of premarital sexual behavior, the greater the adolescent to premarital sexual behavior. The measurement scale was continous and transformed into a dichotomous, coded o for unsupportive and 1 supportive.

Perceived behavior control was defined as the response of adolescents to premarital sexual behavior. The stronger the perception of behavioral control, it will reduce premarital sex behavior. The measurement scale was continous and transformed into dichotomous, coded $\mathrm{o}$ for strong and 1 for weak.

Family intimacy was defined as a feeling of mutual trust, sharing, openness, closeness, bondage and interconnection between two or more individuals who affiliated because of blood relations, marital relationships or appointment and living in a household. The stronger the intimacy of the family, it will reduce premarital sexual behavior. The measurement scale was continuous and converted into a dichotomous, coded o for strong and 1 for weak.

Peer influence was defined as teenagers who have the same age and maturity level and carry out activities together, mutual understanding, trust, and respect. The more positive the influence of peers, the higher the influence for premarital sexual behavior. The measurement scale was continuous and converted into a dichotomous for the sake of analysis with coded o for nega- tive and 1 for positive.

Premarital sex behavior was defined as a sexual activity carried out by individuals with other people before marriage. The scale was continuous and converted into a dichotomous, coded o fot not to engage in premarital sexual behavior and 1 for conduct premarital sexual behavior.

\section{Data Analysis}

Univariate analysis was performed to examine the frequency distribution and characteristics of the study subjects. Bivariate analysis was performed using the chi-square and calculation of the Odds Ratio (OR) with a 95\% Confidence Level (CI) to study the relationship between premarital sex behavior and independent variables. Multivariate analysis was performed using logistic regression through a multilevel approach as indicated by the value of Intra Class Corelation (ICC).

\section{Research Ethics}

The research ethics include informed consent, anonymity, confidentiality, and ethical clearance. Research ethics was obtained from Dr. Moewardi hospital, Surakarta, Central Java based on the decree number: 356/UN27.6/KEPK/2018.

\section{RESULTS}

\section{Sample Characteristic}

The frequency distribution of the characteristics of the study subjects were describe in Table 1.

Table 1. Sample Characteristics

\begin{tabular}{lcc}
\hline Characteristics & n & \% \\
\hline Gender & & \\
Male & 115 & 51.1 \\
Femae & 110 & 48.9 \\
\hline
\end{tabular}

Table 1 showed that the majority of the study subjects were male as much as 115 subjects (51.1\%). 
Table 2. Univariate Analysis

\begin{tabular}{|c|c|c|}
\hline Variables & $\mathbf{n}$ & $\%$ \\
\hline \multicolumn{3}{|l|}{ Intention } \\
\hline Strong & 139 & 61.8 \\
\hline Weak & 86 & 38.2 \\
\hline \multicolumn{3}{|l|}{ Attitude } \\
\hline Positive & 105 & 46.7 \\
\hline Negative & 120 & 53.3 \\
\hline \multicolumn{3}{|c|}{ Subjective Norm } \\
\hline Supportive & 137 & 60.9 \\
\hline Did not support & 88 & 39.1 \\
\hline \multicolumn{3}{|l|}{ Peer } \\
\hline Positive & 138 & 61.3 \\
\hline Negative & 87 & 38.7 \\
\hline \multicolumn{3}{|l|}{ PBC } \\
\hline Strong & 115 & 51.1 \\
\hline Weak & 110 & 48.9 \\
\hline \multicolumn{3}{|c|}{ Family Intimacy } \\
\hline Strong & 120 & 53.3 \\
\hline Weak & 105 & 46.7 \\
\hline
\end{tabular}

2. Bivariate Analysis

Bivariate analysis was conducted to inves- tigate the relationship of independent variables (intention, subjective norm, peer, perceived behavior control, and family intimacy) with the dependent variable (premarital sexual behavior). Table 3 showed the results of bivariate analysis.

Table 3 showed that adolescents strong intention $(\mathrm{OR}=3.14 ; 95 \% \mathrm{CI}=1.79$ to 5.49 ; $\mathrm{p}<0.001$ ), positive subjective norm ( $\mathrm{OR}=$ 7.48; 95\% CI=4.09 to $13.6 ; \mathrm{p}<0.001$ ), and strong peers $(\mathrm{OR}=5.44 ; 95 \% \mathrm{CI}=3.03$ to 9.76; $\mathrm{p}<0.001$ ) increased the risk of premarital sexual behavior. Perceived behavioral control $(\mathrm{OR}=0.24 ; 95 \% \mathrm{CI}=0.37$ to 0.42; $\mathrm{p}<0.001)$, attitude $(\mathrm{OR}=0.13 ; 95 \%$ $\mathrm{CI}=0.07$ to $0.25 ; \mathrm{p}<0.001)$, and family intimacy $(\mathrm{OR}=0.49 ; 95 \% \mathrm{CI}=0.28$ to 0.84 ; $\mathrm{p}<0.001)$ decreased the risk of premarital sexual behavior.

Table 3. The Results of Bivariate Analysis

\begin{tabular}{|c|c|c|c|c|c|c|c|c|}
\hline \multirow{3}{*}{ Variable Group } & \multicolumn{4}{|c|}{$\begin{array}{c}\text { Premarital Sexual } \\
\text { Behavior }\end{array}$} & \multirow{3}{*}{$\mathbf{O R}$} & \multicolumn{2}{|c|}{ 95\% CI } & \multirow{3}{*}{$\mathbf{p}$} \\
\hline & \multicolumn{2}{|c|}{ Yes } & \multicolumn{2}{|c|}{ No } & & \multirow{2}{*}{$\begin{array}{c}\text { Lower } \\
\text { Limit }\end{array}$} & \multirow{2}{*}{$\begin{array}{l}\text { Upper } \\
\text { Limit }\end{array}$} & \\
\hline & $\mathbf{n}$ & $\%$ & $\mathbf{n}$ & $\%$ & & & & \\
\hline \multicolumn{9}{|l|}{ Intention } \\
\hline Strong & 92 & 73.6 & 47 & 53.0 & 3.14 & 1.79 & 5.49 & $<0.001$ \\
\hline Weak & 33 & 26.4 & 53 & 47.0 & & & & \\
\hline \multicolumn{9}{|l|}{ Attitude } \\
\hline Positive & 33 & 26.4 & 72 & 72.0 & 0.13 & 0.07 & 0.25 & $<0.001$ \\
\hline Negative & 92 & 73.6 & 28 & 28.0 & & & & \\
\hline \multicolumn{9}{|l|}{ Subjective Norm } \\
\hline Supportive & 101 & 80.9 & 36 & 36.0 & $7 \cdot 48$ & 4.09 & 13.68 & $<0.001$ \\
\hline Unsupportive & 24 & 19.2 & 64 & 64.0 & & & & \\
\hline \multicolumn{9}{|l|}{ Peer } \\
\hline Positive & 98 & 78.4 & 40 & 40.0 & 5.44 & 3.03 & 9.76 & $<0.001$ \\
\hline Negative & 27 & 21.6 & 60 & 60.0 & & & & \\
\hline \multicolumn{9}{|l|}{ PBC } \\
\hline Strong & 45 & 36.0 & 70 & 70.0 & 0.24 & 0.37 & 0.42 & $<0.001$ \\
\hline Weak & 80 & 64.0 & 30 & 30.0 & & & & \\
\hline \multicolumn{9}{|l|}{ Family Intimacy } \\
\hline Strong & 53 & 45.6 & 63 & 63.0 & 0.49 & 0.28 & 0.84 & $<0.001$ \\
\hline Weak & 68 & 54.4 & 37 & 37.0 & & & & \\
\hline
\end{tabular}


Journal of Health Promotion and Behavior (2018), 3(4): 240-247

https://doi.org/10.26911/thejhpb.2018.03.04.03

Table 4. The Results of Multilevel Analysis

\begin{tabular}{|c|c|c|c|c|}
\hline \multirow{2}{*}{ Independent Variables } & \multirow{2}{*}{ b } & \multicolumn{2}{|c|}{$95 \% \mathrm{CI}$} & \multirow[b]{2}{*}{$\mathbf{p}$} \\
\hline & & Lower Limit & Upper Limit & \\
\hline Intention & 2.70 & 0.50 & 3.15 & 0.007 \\
\hline Attitude & $-4 \cdot 31$ & -4.15 & -1.55 & 0.000 \\
\hline Subjective norm & 4.66 & 1.89 & 4.63 & 0.000 \\
\hline Peers & 4.34 & 1.99 & 5.28 & 0.000 \\
\hline Perceived behavioral control & -2.37 & -2.37 & -0.23 & 0.018 \\
\hline Family intimacy & -2.44 & -2.44 & -0.29 & 0.015 \\
\hline Var (constants) & 5.77 & 2.05 & 16.2 & \\
\hline \multicolumn{5}{|l|}{$\mathrm{N}$ observation $=225$} \\
\hline \multicolumn{5}{|l|}{$\mathrm{N}$ group $=25$} \\
\hline \multicolumn{5}{|l|}{ Average group $=9, \min =9, \max =9$} \\
\hline \multicolumn{5}{|l|}{ Log likelihood= -70.70} \\
\hline $\mathrm{p}<0.001$ & & & & \\
\hline $\mathrm{ICC}=63.72 \%$ & & & & \\
\hline
\end{tabular}

Table 4 showed that intention, subjective norms, peers, perceived behavioral control, and family intimacy have a statistically significant influence on premarital sexual behavior.

Analysis of the data at the school level showed an ICC score of $63.72 \%$, this indicated that variations in premarital sexual behavior by $63.72 \%$ were determined by variables at the school level. The ICC score in this study was greater than the 8-10\% rule of thumb, then the contextual influence which was school was very important to note.

\section{DISCUSSION \\ 1. The effect of intention on pre- marital sexual behavior}

The result of this study showed that there was a significant effect of intention on premarital sexual behavior $(b=2.70 ; 95 \% \mathrm{CI}=$ 0.50 to $3.15 ; \mathrm{p}=0.007$ ). Adolescents with strong intentions have a greater chance to have premarital sexual behavior by 2.05 units compared to adolescents with weak intentions. This was in line with a study done by Adeoye et al., (2012) which stated that teenagers who have sexual activity for the first time did not have the intention to do so, but because the situations and conditions that support the teenager to have sexual activity without realizing it. For the second and third times, teenagers have sexual activity with their partners along with the intentions because they have begun to get used to and have become a necessity.

\section{The effect of attitude on premarital sexual behavior}

The result of this study showed that there was a significant effect of attitude on premarital sexual behavior $(b=-4.31 ; 95 \% \mathrm{CI}=-$ 4.15 to -1.55 ; $\mathrm{p}<0.001$ ). Adolescents with a positive attitude were 4.31 times less likely to have premarital sexual behavior compared to adolescents who have negative attitude.

A positive attitude towards premarital sexual behavior was one of the main factors of premarital sexual behavior. A positive attitude towards premarital sexual behavior which was believed by adolescents can bring them to premarital sexual behavior. If adolescents have a positive attitude, they would make them think more about premarital sex (Eze, 2014).

\section{The effect of subjective norm on premarital sexual behavior}

The result of this study showed that there was a significant effect of subjective norm on premarital sexual behavior $(b=4.66$; 95\% $\mathrm{CI}=1.89$ to $4.63 ; \mathrm{p}<0.001)$. Adoles- 
cents with subjective norms that support premarital sexual behavior were more likely to have premarital sexual behavior by 4.66 units compared to adolescents with subjective norms that did not support premarital sexual behavior.

Subjective norms were formed after the individuals have normative beliefs, namely the extent to which individuals were willing to cheat based on the people around them, for example if individuals were in an environment where the people have premarital sex, then surely the individuals would tend to conduct premarital sexual behavior, while if the individual was in an environment that considered premarital sex behavior to be immoral, they would avoid this behavior. Thus, individuals considered the opinions of others about premarital sexual behavior and were motivated to have premarital sex or not, according to what the closest people wanted (Rosenbaum, 2013).

\section{The effect of peers on premarital sexual behavior}

The result of this study showed that there was a significant effect of peers on premarital sexual behavior $(b=4.34$; $95 \% \mathrm{CI}=$ 1.99 to 5.28 ; $\mathrm{p}<0.001)$. Adolescents with peer groups who have a positive attitude to premarital sexual behavior were more likely to have premarital sexual behavior by 4.34 units compared to adolescents with peers who have a negative attitude.

There was a very significant and positive relationship between group conformity with premarital sexual behavior where subjects who have the highest group conformity tend to often do premarital sexual behavior, whereas teenagers who have low conformity tend to rarely have sex. Doing sexual activity was influenced by friends because they immitated what their friends did. Peers were also a significant source of information about sex in shaping know- ledge, attitudes, and sexual behavior (Jaya and Hindin, 2009).

\section{The effect of perceived behavioral control on premarital sexual beha- vior}

The result of this study showed that there was a significant effect of perceived behavioral control on premarital sexual behavior $(b=-2.37 ; 95 \% \mathrm{CI}=-2.37$ to $5.28 ; \mathrm{p}=0.018$ ). Adolescents with perceived behavioral control that strongly prevent premarital sexual behavior were less likely to have premarital sexual behavior by 2.37 units compared to adolescents with a weak perceived behavioral control.

Perception itself was a meaning of the results of thinking, especially in terms of observation, it was closely related to the environment and culture that was able to become stimuli for individuals. A teenager who has a good perceived behavioral control would be more able to control themselves to do something including premarital sexual behavior (Ofori and Dodoo, 2013).

\section{The effect of family intimacy on premarital sexual behavior}

The result of this study showed that there was a significant effect of family intimacy on premarital sexual behavior $(b=-2.44$; 95\% CI $=-2.44$ to $0.29 ; \mathrm{p}=0.015$ ). Adolescents with strong family intimacy were less likely to have premarital sex by 2.44 units compared to adolescents with weak family intimacy.

The influence of parents, the lack of open communication between parents and adolescents in sexual problems can strengthen the emergence of sexual behavior deviations. Moreover, if the adolescents were not very close to parents and families, they would had lack of information about premarital sexual behavior that caused less monitored adolescents about their sexual behavior. Adolescents who were close to family and parents were very open about 
Journal of Health Promotion and Behavior (2018), 3(4): 240-247

https://doi.org/10.26911/thejhpb.2018.03.04.03

sexual behavior and would get more information and monitoring from parents and families (Abdullahi and Umar, 2013).

\section{The effect of school level on pre- marital sexual behavior}

The results of the study showed that there was a contextual influence of the school level on the variation of premarital sexual behavior $(\mathrm{ICC}=63.72 \%)$. The variations of premarital sexual behavior by $63.72 \%$ were determined by variables at the school level. The ICC score in this study was greater than the $8-10 \%$ rule of thumb, then the contextual influence which was school was very important to note.

School was a place of education where a person would gain knowledge. Schools have an important role in education. Both formal and informal education. There were still many schools that have not provided sex education in adolescents. Even though sex education was the most important thing. Because most adolescents have insufficient knowledge about premarital sex, they would have premarital sexual behavior (Rahmani et al., 2016).

Based on the results of the study, it can concluded that there was a significant effect of intention, attitude, peers, subjecttive norms, perceived behavioral control and family intimacy on premarital sexual behavior. Variations at the school level indicated that there was a contextual effect on premarital sexual behavior.

\section{REFERENCES}

Abdullah M, Umar A (2013). Consequences of Premarital Sex among the Youth a Study of University of Maiduguri. IOSR Journal Of Humanities and Social Science 10(1): 10-17.

Adeoye AO, Omolayo O, Bose A (2012). Prevalence of premarital sex and factors influencing it among students in a private tertiary institution in Nige- ria. International Journal of Psychology and Counselling, 4(1): 6-9.

Chihurumnanya A, et al (2016). Premarital Sex, Safer Sex and Factors Influencing Premarital Sex Practices among Senior Secondary School Students in Ebonyi Local Government Area of Ebonyi State Nigeria J Community Med Public Health Care 2016 3: 12. Doi: 10.24966/CMPH-1978/100012.

Darroch J, Woog V, Bankole A, Ashford LS (2016). Adding it Up: Costs and Benefits of Meeting The Contraceptive Needs of Adolescents. New York: Guttmacher Institute. https://www.unfpa.org/publications/adding-it-2012. Accessed on May $19^{\text {th }}, 2018$.

Eze IR (2014). Adolescents' Attitude Towards Premarital Sex. Mediterranean Journal of Social Sciences. 5(10): 491499. Doi: 10.5901/mjss.2014.v5n1op491.

Kusumaryani, M (2017). Ringkasan Studi: Prioritaskan Kesehatan Reproduksi Remaja Demografi. Jakarta: Lembaga Demografi Fakultas Ekonomi dan Bisnis Universitas Indonesia. http://ldfebui.org/wp-contentuploads/2017/o8/BN-06-2017.pdf. Accessed on May $19^{\text {th }}, 2018$.

Jaya, Hindin MJ (2009). Premarital Romantic Partnerships: Attitudes and Sexual Experiences of Youthin Delhi, Indi. Int Perspect Sex Reprod Health. 35(2):97-104. doi: 10.1363/ipsrh.35.097.09.

Ofori C, Dodoo FNA (2013). Young people's perceptions about premarital sex, perceived parent values about sex and premarital sexual behaviour in Ghana.

Pringle et al., Cogent Social Sciences (2017) 3: 1368858. https://doi.org/10.1080/23311886.2017.1368858. Accessed May 2018. 
Rahmani A, Khoei EM, Banaem LM, Hajizadeh E, Montazeri A (2016). View points of sexually active single women about premarital sexual Relationships: A Qualitative Study in the Iranian Context. Int J High Risk Behav Addict. 5(1): e23159.

Rosenbaum JE (2013). True Love Waits: Do Southern Baptists? Premarital Sexual Behavior among Newly Married
Southern Baptist Sunday School Student. J Relig Health. 52(1): 263-75. doi: 10.1007/s10943-010-9445-5.

UNFPA (2017). Adolescent pregnancy: Overview. https://www.unfpa.org/adolescent pregnancy. Accessed May $10^{\text {th }}, 2018$.

WHO (2012). Adolescent Health. http://www.who.int/topics/adolescent_heal th/en/ . Accessed May 10 ${ }^{\text {th }}, 2018$. 